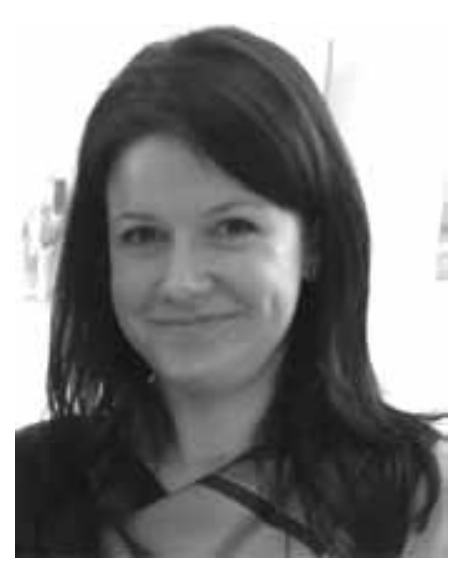

Raimonda Mikašauskienė - humanitarinių mokslų daktaré, Klaipėdos universiteto Socialinių ir humanitarinių mokslų fakulteto Filologijos katedros lektorè Moksliniai interesai: baltistika, veiksmažodžio istorija, lyginamoji kalbotyra El.paštas: raisaryte@gmail.com

Raimonda Mikašauskienè - $\mathrm{PhD}$ in Philology, lecturer of Department of Philology of the Faculty of Social and Humanitarian Sciences, Klaipeda University

Research interests: Baltic studies, history of verb, Comparative linguistics

E-mail: raisaryte@gmail.com

\title{
Raimonda Mikašauskienè
}

Klaipedos universitetas

\section{„ZIWATO “ IR „PURPUROS “ INTARPINIŲ IR $S T A$ KAMIENO VEIKSMAŽODŽIŲ MORFOLOGINÉ STRUKT ŪRA}

\section{Anotacija}

Straipsnyje pristatoma dvieju šiaurès žemaičių kretingiškių tarmei atstovaujančių šaltinių - „Ziwato“ (1759) ir „Purpuros isganima“ (tiksli leidimo data nežinoma) - intarpinių ir sta kamieno veiksmažodžių morfologinè struktūra. Šiuose šaltiniuose užfiksuoti intarpiniai ir sta kamieno veiksmažodžiai analizuojami morfologinès struktūros požiūriu gretinant juos su XX a. antrojoje pusejje surinktame „Kretingos tarmės žodyne“ pateiktais duomenimis ir išryškinant analizuojamų veiksmažodžiu sistemos kitimus bei inovacijas. Gauti duomenys lyginami ir su kitų šiaurès žemaičių kretingiškių autorių - Motiejaus Valančiaus ir Simono Daukanto - kalbos faktais bei „Lietuvių kalbos žodyno" duomenimis.

PAGRINDINIAI ŽODŽIAI: žemaičių tarmė, konstrukcinis įvairavimas, intarpiniai ir sta kamieno veiksmažodžiai, šaknies finalè, na kamienas, morfologinè struktūra.

\footnotetext{
Abstract

The article focuses on the morphological structure of infixed and sta-stem verbs in two written sources in the north Samogitian dialect of Kretinga, in particular Ziwatas and Purpura. The verbs in question are analysed in terms of their morphological composition, by comparing them to those recorded in a dictionary of the Kretinga dialect, and highlighting the changes and innovations that took place in the verbal system. The data gathered is further compared to linguistic facts regarding two authors using the same Kretinga dialect, Motiejus Valančius and Simonas Daukantas, and also to data provided by the Dictionary of the Lithuanian Language.

KEY WORDS: dialect of Samogitia, constructional variation, infixed and sta-stem verbs, final consonant of the verb root, $n a$-stem, morphological structure.
} 
Ivadinès pastabos

Straipsnyje analizuojama dviejų šiaurès žemaičių kretingiškių tarmei atstovaujančių šaltinių - „Ziwato“ ir „Purpuros isganima“ - intarpinių ir sta kamieno veiksmažodžių morfologinè struktūra. Šiuose paminkluose užfiksuoti veiksmažodžiai tyrinèti gana fragmentiškai, tad šiuo straipsniu siekiama prisidèti prie dar negausių žemaitiškojo veiksmažodžio tyrimų ir papildyti jau esamus senųjų raštų duomenis.

1759 m. Vilniuje išleistas šv. Bonaventūros veikalo „Ziwatas Pona yr Diewa musu Jezusa Christusa“ vertimas, šiame straipsnyje vadinamas „Ziwatu“, kalbos istorijos tyrimams svarbus tuo, kad yra vienas pirmųiu spausdintų žemaitiškų tekstų, kuriame puikiai išlaikytos senosios žemaičių tarmės ypatybès (apie jas plačiau žr. Subačius 1998, 45-48), o rašyba stengtasi perteikti anuomet dar raštuose nelabai įprastus žemaitiškus fonetinius junginius (Girdenis, Girdenienè 1997, 19-25). Lietuviškasis „Ziwato“ vertimas vien XVIII a. buvo išleistas net tris kartus, tiesa, pirmasis leidimas (1753) dar neatrastas. Juozo Aleksandravičiaus ir Jono Palionio teigimu, „Ziwatą“ galima laikyti geriausia XVIII a. šiaurès žemaičių tarmès spausdinta knyga, kuri, pasak Giedriaus Subačiaus, padejo pamatus žemaitiškos rašomosios kalbos tradicijai ir padarė nemažą ịtaką tokiems vèliau žemaičių tarme rašiusiems autoriams kaip Daukantas, Klementas, Pabrèža ir daugeliui kitų $(1998,57)$. „Ziwato“ tarmès fonologinė ir morfonologinè sistema jau aprašyta (Girdenis, Girdenienè 1997, 19-44), aptarta ir keletas morfologinių aspektų (Rosinas 1995, 25-27; Vaičiakauskytė 2002), tačiau šio paminklo veiksmažodžių tyrimai dar nesulaukè didesnio dèmesio.

Kitas šiame straipsnyje tiriamas šaltinis „Purpura iszganima mukos Iezusa“, šiame straipsnyje sutrumpintai vadinamas tiesiog „Purpura“, gana mịslingas kol kas nežinomas nei originalas, iš kurio šis veikalas išverstas, nei jo vertejjas ar vertimą perrašęs asmuo. Šio paminklo antraštiniame lape nurodyti 1707 metai tyrèjams buvo tikras galvosūkis - iš pradžių manyta, kad „Purpura“ yra XVIII a. pradžios tekstas, taigi penkiasdešimčia metų senesnis ir už „Ziwatą“ (Aleksandravičius, Palionis 1998, 126). Vis dèlto vėlesni šio šaltinio tyrimai atskleide, kad rankraštis parengtas gerokai vèliau - tyrejjų manymu, „Purpura“ galèjo būti parašyta apie XIX a. vidurị, o data antraštiniame lape galètų nurodyti originalą, iš kurio buvo verčiama. Tokią išvadą paremia abiejų senųjų raštų rašybos ir kalbos faktu skirtumai: „Purpuros“ rašyba yra naujoviškesnè ir paprasčiau perteikia šiaurès žemaičių kretingiškių garsyną nei 1759 m. išleistas „Ziwatas“ (plačiau žr. Purpura 2009, 327-330; Girdenis 2005, 17-44). „Purpuros“ paminklas svarbus tuo, kad jame labai nuosekliai fiksuojama šiaurès žemaičių kretingiškių tarmè, gana artima dabartinei - ji daug modernesnè negu 1759 metų 
„Ziwate“, parašytame tos pačios tarmès pagrindu (Girdenis 2009, 5). Remdamiesi rankraščio grafikos ir tam tikrų tarmès faktų analize, Regina Venckutė ir Giedrius Subačius iškèlè svarią mintį, kad „Purpuros“ teksto ypatybės skatina jo autoriaus ieškoti tarp Daukanto ir Valančiaus amžininkų, o ne XVIII a. pradžioje, kaip manyta anksčiau (Venckutè, Subačius 1999, 196-197).

Minètus šaltinius apytikriai skiria šimtas metų, tad galima teigti, kad abu paminklai atskleidžia skirtingus tos pačios šiaurès vakarų kretingiškių tarmès raidos etapus. Pasak Alekso Girdenio, „Purpura“ yra svarbi jungiamoji grandis tarp „Ziwate“ atspindètos XVIII a. tarmès ir šių dienų šiaurès žemaičių kretingiškių, nes fonetikos ir morfologijos ypatybėmis jos kalba gerokai artimesnè dabartinėms Kretingos apylinkių šnektoms (Girdenis 2009, 345). Žvelgiant istoriškai, šimto metuc skirtumas nedidelis, tačiau neabejotina, kad ir per tokị trumpą laiką kalboje (šiuo atveju - tarmèje) gali įvykti apčiuopiamų pokyčių, tą patvirtina vien grafikos tendenciju pokyčiai, paliudyti „Purpuroje“. Šio straipsnio tikslas - palyginti šiuose šaltiniuose užfiksuotus intarpinius ir sta kamieno veiksmažodžius morfologinès struktūros požiūriu, gretinant juos su „Kretingos tarmès žodyne" surinktais duomenimis ir išryškinant analizuojamų veiksmažodžių sistemos kitimus bei inovacijas. Gauti duomenys lyginami ir su kitų šiaurès žemaičių kretingiškių autorių - Motiejaus Valančiaus ir Simono Daukanto - kalbos faktais bei „Lietuvių kalbos žodyno“ (LKŽ) duomenimis.

\section{Morfologiné struktūra}

\section{Trumposios šaknies veiksmažodžiai}

Tirtuose raštuose paliudyti 28 trumpąją šaknį turintys analizuojamojo tipo veiksmažodžiai. Veiksmažodžiu registro lentelèse pateikiamos tik šių veiksmažodžiu esamojo ir būtojo laiko formos.

\section{1. $C V T$ tipas}

Sprogstamuoju priebalsiu besibaigiančių veiksmažodžių užfiksuota 14: bus$t i$,išeiti iš miego būklès“, justi ,jausti išorinius ir išvidinius dalykus“, kristi „staigiai leistis žemyn, pulti; birti“, migti „pradèti miegoti“, prasti „gusti, junkti (ką daryti); pagauti prasmę“, pusti „tinti, brinkti“, rasti „,ieškant aptikti, užeiti ką pamestą“", snigti „kristi sniegui“, smegti „lįsti gilyn, klimpti, grimzti“, šlikti „lašèti, tikšti“, šukti „,̌̌aukti, rikti, sušukti“, švisti ,aušti, brèkšti“, tapti „,darytis kokiam, virsti kuo; pasidaryti, įvykti, tiktis“, tekti „kliūti į dalì, būti gautam; užtekti, pakakti, netrūkti“, tikti ,būti atitaikytam, tinkamam, geram; būti pritai- 
komam kokiam nors reikalui, derèti; būti pagal skonį, patikti; pasidaryti, nusiduoti, ịvykti, atsitikti; pasitaikyti, būti“.

1 lentelè

\begin{tabular}{|c|c|c|c|}
\hline $\begin{array}{l}\text { Veiks- } \\
\text { mažodis }\end{array}$ & „Ziwatas“ & „Purpura“ & Kiti autoriai \\
\hline \multirow[t]{2}{*}{ busti } & pabunda $\mathrm{ZwVI}_{23}$ & - & - \\
\hline & atfybuda Zw124 & - & - \\
\hline \multirow[t]{2}{*}{ justi } & $\begin{array}{l}\text { juntate } \mathrm{Zw} 157_{17} \\
\text { junta } \mathrm{Zw} 50_{11}\end{array}$ & juntontys Purp97v25 & junta S. Dauk. \\
\hline & jutaw Zw68 & - & pajutau VPJ1863 28 \\
\hline \multirow[t]{2}{*}{ kristi } & - & $\begin{array}{l}\text { krimt Purp131v6 } \\
\text { krimtontys } \\
\text { Purp266r19 }\end{array}$ & $\begin{array}{l}\text { krimta S. Dauk. } \\
\text { krimtantes VVK1868 } 81\end{array}$ \\
\hline & - & nukryta* Purp239r12 & $\begin{array}{l}\text { krita VPJ186340 } \\
\text { ikrita VPJ1863 } 43 \\
\text { pakrito S. Dauk. } \\
\end{array}$ \\
\hline \multirow[t]{2}{*}{ migti } & - & ożmingąnti Purp111r12 & - \\
\hline & użmyga Zw150 & $\begin{array}{l}\text { ożmyga Purp81r3; } \\
\text { Purp189v7 }\end{array}$ & - \\
\hline \multirow[t]{2}{*}{ prasti } & $\begin{array}{l}\text { ne fuprątąnćius } \\
\mathrm{Zw} 159_{3-4}\end{array}$ & ne sopronti Purp18r7 & $\begin{array}{l}\text { nusuprantu VPJ1863 } 25 \\
\text { ne suprant VPJ1863 } 38 \\
\text { suprant VVK1868 } 3\end{array}$ \\
\hline & $\begin{array}{l}\text { suprata } \mathrm{Zw} 23_{15} \\
\text { fufyprata } \mathrm{Zw} 117_{25}\end{array}$ & $\begin{array}{l}\text { sopratosi Purp176r17 } \\
\text { nebsoprata Purp218r28 }\end{array}$ & $\begin{array}{l}\text { supratau VPJ1863 } 25 \\
\text { susipratau VPJ1863 } 38\end{array}$ \\
\hline \multirow[t]{2}{*}{ rasti } & $\begin{array}{l}\text { atrąd }^{* *} \mathrm{Zw} 210_{23}, \\
\text { atrądu } \mathrm{Zw} 215_{23} \\
\text { yfzrądat } \mathrm{Zw} 189\end{array}$ & - & $\begin{array}{l}\text { atrąnda VPJ186392 } \\
\text { randam VPJ1863 } 103 \\
\text { randam VVK1868 } 89\end{array}$ \\
\hline & $\begin{array}{l}\text { atradaw } \mathrm{Zw} 95_{13} \\
\text { atradoma } \mathrm{Zw} 193_{15}, \\
\text { atrada } \mathrm{Zw} 15_{9}\end{array}$ & $\begin{array}{l}\text { atrand Purp117v12 } \\
\text { atrond Purp16v16 } \\
\text { iszrand Purp126v6 } \\
\text { atrada Purp122r9 } \\
\text { neatsyrada Purp39r24 }\end{array}$ & atrada VVK18683 \\
\hline \multirow[t]{2}{*}{ smegti } & - & - & - \\
\hline & parfmega Zw332 & - & nesmego S. Dauk. \\
\hline \multirow[t]{2}{*}{ snigti } & - & - & - \\
\hline & - & snyiga Purp230r8 & $\begin{array}{l}\text { sniga VPJ1863 } 102 \\
\text { antsnigo S. Dauk. }\end{array}$ \\
\hline \multirow[t]{2}{*}{ šlikti } & - & - & - \\
\hline & antfzlyka Zw247 & - & nušlikai M. Valanč. \\
\hline
\end{tabular}




\begin{tabular}{|c|c|c|c|}
\hline $\begin{array}{l}\text { Veiks- } \\
\text { mažodis }\end{array}$ & „Ziwatas“ & „Purpura“ & Kiti autoriai \\
\hline \multirow[t]{2}{*}{ šukti } & - & - & - \\
\hline & $\begin{array}{l}\text { prafzuka } \mathrm{Zw} 119_{8-9} \\
\text { fufzuka } \mathrm{Zw} 165_{17}\end{array}$ & $\begin{array}{l}\text { (balsu) soszoka } \\
\text { Purp113r16 }\end{array}$ & $\begin{array}{l}\text { suszukom VPJ1863 } 11 \\
\text { suszuka VPJ1863 } 14\end{array}$ \\
\hline \multirow[t]{2}{*}{ švisti } & - & - & - \\
\hline & - & isz szwyta Purp235v17 & praszwita VPJ1863 54 \\
\hline \multirow[t]{2}{*}{ tapti } & - & - & - \\
\hline & tape $\mathrm{Zw} 250_{20}$ & - & $\begin{array}{l}\text { tapo S. Dauk. } \\
\text { tape M. Valanč. }\end{array}$ \\
\hline \multirow[t]{2}{*}{ tekti } & - & $\begin{array}{l}\text { neożtenk Purp124v4 } \\
\text { nedatenk Purp165r7 }\end{array}$ & tenka S. Dauk. \\
\hline & $\begin{array}{l}\text { neteka } \mathrm{ZwIV}_{25} \\
\text { ne teka } \mathrm{Zw}_{19} 3_{19}\end{array}$ & - & $\begin{array}{l}\text { teka VPJ1863 } 29 \\
\text { nebteka VPJ1863 } 56 \\
\text { nutekau VPJ1863 } 77\end{array}$ \\
\hline \multirow[t]{2}{*}{ tikti } & - & - & $\begin{array}{l}\text { atsitink VVK1868 } 69 \\
\text { tinka S. Dauk. }\end{array}$ \\
\hline & futyka Zw47 & $\begin{array}{l}\text { sotink Purp229r8 } \\
\text { sosytyka Purp162r1 }\end{array}$ & sutika VPJ1863 5 \\
\hline
\end{tabular}

Grafema $<y>$ „Purpuroje“ visuomet reiškia balsius [ẹ ẹ.], kilusius iš ?-i-p (Girdenis 2009, 360).

"* „Ziwate“, kaip, beje, ir „Purpuroje“, neretai pasitaiko $q$ ir $q$ n alternacijų dvibalsiui [on] žymèti. Girdeniai atkreipè dèmesį, kad toks nenuoseklumas ypač būdingas pozicijoje prieš sprogstamuosius priebalsius: „dažnesniuose žodžiuose $a$ prieš sprogstamuosius beveik reguliariai kaitaliojasi su $q n^{\prime \prime}(1997,24)$.

1.1.1. Esamasis laikas. Veiksmažodžiai, kuriu šaknis baigiasi sprogstamuoju priebalsiu, eksplikuoja itin stabilią esamojo laiko struktūrą - abiejuose tiriamuose šaltiniuose paliudytos tik intarpinės analizuojamų veiksmažodžiu formos, tokios fiksuojamos ir Valančiaus, Daukanto darbuose bei „Kretingos tarmès žodyne“. Sprendžiant iš veiksmažodžio kristi esamojo laiko formų krimta, užfiksuotų „Purpuroje“ ir Daukanto bei Valančiaus raštuose, galima manyti, kad tokia buvo vartojama ir „Ziwato“ išleidimo laikais. Ši forma paliudyta ir „Kretingos tarmès žodyne“. Už šios tarmès ribų žemaičiai telšiškiai vartoja dvejopas formas krinta bei krimta, o pietu žemaičiai - naujesnès struktūros morfologini alternantą kremta (apie šio veiksmažodžio šaknies vokalizmą žr. Pakalniškienė 1997, 108-109). Paminètina, kad veiksmažodis bristi „Purpuroje“ (kaip ir „Kretingos tarmès žodyne") turi išlaikytą archajiškesnę $a$ kamieno struktūrą, plg. bredąntis Purp103v291.

LKŽ duomenimis, apie Salantus ir Platelius vartojama ir intarpine šio veiksmažodžio forma brinda. 
1.1.2. Būtasis laikas. Analizuojamų veiksmažodžių būtojo laiko formų sistema minètuose raštuose gana tolygi, dominuoja konstrukciškai ikoniškos $o$ kamieno formos. İvairuoja tik veiksmažodžio tapti būtojo laiko formos: „Ziwate“ užfiksuota $\dot{e}$ kamieno forma tape, kuri paliudyta ir Valančiaus, nors Daukantas yra užrašęs o kamieno formą tapo. Tokių šio veiksmažodžio dvejopų formų fiksavimas pastebėtas tiek Mažosios, tiek Didžiosios Lietuvos autorių paminkluose (žr. Mikašauskienè 2018, 50-51), o LKŽ fiksuoja šią formą vakarų žemaičių plote - apie Priekulę ir Šilutės apylinkèse.

\section{2. $C V R$ tipas}

Sonantu besibaigiančių veiksmažodžių paliudyta 13: balti „darytis baltam, baltèti“, būti „reikštis, rodytis, rastis“, džiūti „darytis sausam, sausèti“, gyti „sveikti, taisytis; igauti, igyti“, lyti, milti „,imti myleti““, mirti „,netekti gyvybès, nustoti gyventi“, pūti ,,smukti, gesti“, ryti ,sukramtytą maistą ar ką kita pro ryklę stumti į skrandi்“, senti ,darytis senam“, šalti „,būti šaltam orui, laikytis šalčiui; šaltyje būnant, ką darant pašalti“, temti ,tamsèti, eiti tamsyn“, žilti ,,darytis žilam, netekti tam tikrų pigmentų“.

2 lentelè

\begin{tabular}{|c|c|c|c|}
\hline $\begin{array}{l}\text { Veiks- } \\
\text { mažo- } \\
\text { dis }\end{array}$ & „Ziwatas“ & „Purpura“ & Kiti autoriai \\
\hline \multirow[t]{2}{*}{ balti } & balfta Zw77 ${ }_{27}$ & - & - \\
\hline & yfbała Zw5 $5_{13}$ & - & - \\
\hline \multirow[t]{2}{*}{ būti } & - & $\begin{array}{l}\text { pribun Purp7r16; } \\
\text { Purp155r29 }\end{array}$ & - \\
\hline & - & - & $\begin{array}{l}\text { buvo S. Dauk. } \\
\text { buvo M. Valanč. }\end{array}$ \\
\hline \multirow[t]{2}{*}{ džiūti } & - & - & $\begin{array}{l}\text { išdžiūna S. Dauk. } \\
\text { džiūst S. Dauk. }\end{array}$ \\
\hline & - & $\begin{array}{l}\text { iszdżiuwa Purp27r1 } \\
\text { iszdzjuwa Purp193v23 }\end{array}$ & - \\
\hline \multirow[t]{2}{*}{ gyti } & - & igin Purp34r20 & atgyna S. Dauk. \\
\hline & $\begin{array}{l}\text { atgyie } \mathrm{Zw} 264_{2-3} \\
\text { igije } \mathrm{Zw} 320_{10}\end{array}$ & - & $\begin{array}{l}\text { igije VPJ1863 } 10 \\
\text { pagije VVK1868 } 31\end{array}$ \\
\hline \multirow[t]{2}{*}{ lyti } & - & - & - \\
\hline & - & lyje Purp226r24 & - \\
\hline
\end{tabular}




\begin{tabular}{|c|c|c|c|}
\hline $\begin{array}{l}\text { Veiks- } \\
\text { mažo- } \\
\text { dis }\end{array}$ & „Ziwatas“ & „Purpura“ & Kiti autoriai \\
\hline \multirow[t]{2}{*}{ milti } & $\begin{array}{l}\text { ne fufymylsti } \mathrm{Zw} 142_{6} \\
\text { ne fufymylftate } \mathrm{Zw} 247_{11}\end{array}$ & - & - \\
\hline & - & - & - \\
\hline \multirow[t]{2}{*}{ mirti } & $\begin{array}{l}\text { numyrftu Zw129 } \\
323_{15-18,} \\
\text { nu myrfzt Zw318 }\end{array}$ & $\begin{array}{l}\text { myrsztonty Purp17r11 } \\
\text { myrszto Purp53r6 } \\
\text { myrsztątem Purp159r6 }\end{array}$ & $\begin{array}{l}\text { mirsztant VVK1868 } 69 \\
\text { miršta S. Dauk. }\end{array}$ \\
\hline & $\begin{array}{l}\text { apmyre } \mathrm{Zw} 124_{6} \\
\text { numyriaw } \mathrm{Zw} 130_{3}\end{array}$ & numyriau Purp110r13 & $\begin{array}{l}\text { apmire VPJ1863 } 34 \\
\text { iszmire VPJ1863 } 80 \\
\text { numire VPJ1863 } 5 \\
\end{array}$ \\
\hline \multirow[t]{2}{*}{ pūti } & nepun Zw1759 289, 23 & - & $\begin{array}{l}\text { pun VVK1868 } 25 \\
\text { pūna S. Dauk. }\end{array}$ \\
\hline & - & - & - \\
\hline \multirow[t]{2}{*}{ ryti } & - & $\begin{array}{l}\text { rin Purp82v11 } \\
\text { rinanty (kuna) Purp83r11 } \\
\text { prarin Purp135r24 }\end{array}$ & apsiryjančius M. Valanč. \\
\hline & - & praryie Purp82v14 & - \\
\hline \multirow[t]{2}{*}{ senti } & - & - & - \\
\hline & - & pasenosi Purp120r3 & - \\
\hline \multirow[t]{2}{*}{ šalti } & - & $\begin{array}{l}\text { neoszał (małony) Pur- } \\
\text { p127v21 }\end{array}$ & szal VPJ1863 17 \\
\hline & ufzala Zw176 14 & - & iššalo S. Dauk. \\
\hline \multirow[t]{2}{*}{ temti } & - & - & - \\
\hline & użtema Zw239, & aptema Purp78r29 & uźtema VVK1868 18 \\
\hline \multirow[t]{2}{*}{ žinti } & $\begin{array}{l}\text { paźiftu } \mathrm{Zw} 103_{5} \\
\text { nepażiftu } \mathrm{Zw} 234_{15} \\
\text { pazifta } \mathrm{Zw} 154_{3} \\
\text { yfzpażiftu } \mathrm{Zw} 300_{8}\end{array}$ & $\begin{array}{l}\text { pażistama Purp3v21 } \\
\text { nepażistat Purp53r3 } \\
\text { prisipażistu Purp12v13 }\end{array}$ & nepažista M. Valanč* \\
\hline & $\begin{array}{l}\text { yfzpażyna } \mathrm{Zw} 232_{5} \\
\text { pażynaw } \mathrm{Zw} 318_{17} \\
\text { nepażyna } \mathrm{Zw} 188_{9}\end{array}$ & $\begin{array}{l}\text { nepażyna Purp77r16 } \\
\text { pripażyna Purp19r25 }\end{array}$ & $\begin{array}{l}\text { iszpaźina } \\
\text { VPJ1863 } 101 \\
\text { prisipaźina } \\
\text { VVK1868 } 15 \\
\end{array}$ \\
\hline
\end{tabular}

Ši santrumpa žymi tuos pavyzdžius, kurių neaptikta tirtuose Valančiaus raštuose, tačiau jie pateikiami LKŽ. 
1.2.1. Esamasis laikas. Veiksmažodžiai, kurių šaknis baigiasi sonantu, iliustruoja kiek margesnę esamojo laiko morfologinę struktūrą.

Sonantais $m$ ir $n$ besibaigiantys veiksmažodžiai analizuojamuose raštuose turi tik sta kamieno formas, tokios užfiksuotos tiek Valančiaus bei Daukanto raštuose, tiek „Kretingos tarmès žodyne“.

Veiksmažodžiai, kurių šaknį uždaro sonantai $v$ ir $j$, turi paliudytas na kamieno formas, nors jų dažnumas analizuojamuose raštuose skiriasi: visame „Ziwate“ paliudyta vos viena na kamieno forma nepun, o „Purpuroje“, kuri datuojama šimtmečiu vèliau, tokių formų jau kur kas daugiau: vien veiksmažodžio ryti $n a$ kamieno forma pavartota šešis kartus, veiksmažodžio gyti - vieną kartą, paliudyta ir veiksmažodžio būti na kamieno forma pribun ${ }^{2}$. Galima daryti prielaidą, kad „Ziwato“ išleidimo metai buvo dar gana ankstyva na kamieno egzistavimo fazè, kuri ilgainiui patyrẻ laipsnišką ekspansiją visame žemaičiu plote (plačiau žr. Mikašauskienė 2018, 75-76; 97-98), kita vertus, net ir Valančiaus bei Daukanto laikais na kamienas dar konkuravo su sta kamieno formomis (plg. Daukanto lytis išdžiūna ir džiūst, Valančiaus formas kiła VPJ1869 82 ir pakilst VVK186859 ir pan.). „Kretingos tarmès žodyne“ (taigi XX a. antrojoje puseje) fiksuojamas $n a$ kamieno formų įsitvirtinimo etapas, mat jame minètą finalę turinčių veiksmažodžiu fiksuojamos vien tik na kamieno formos.

Dalies veiksmažodžių, kurių šaknis baigiasi sonantais $l$ ir $r$, paliudytos sta kamieno formos, tik veiksmažodžio šalti užrašytas esamojo laiko formas galima hipotetiškai priskirti intarpinei struktūrai (apie tokios struktūros interpretaciją žr. Mikašauskienè 2019, 191-192). Beje, „Kretingos tarmès žodyne“ fiksuojamas inchoatyvią reikšmę turinčio veiksmažodžio priesaginis ekvivalentas šaltéti, šaltéja, šaltéjo.

1.2.2. Būtasis laikas. Analizuojamuose raštuose paliudytos tik konstrukciškai ikoniškos $o$ kamieno formos, išskyrus veiksmažodžio mirti, $-\dot{e}$ kamieno formą (plačiau apie šios formos struktūrinę interpretaciją žr. Kiseliūnaitė 1991, 66; Kazlauskas 2000, 330; Svensson 2005, 247).

\section{3. $C V S$ tipas}

„Ziwate“ ir „Purpuroje“ užfiksuotas vos vienas veiksmažodis, kurio šaknis baigiasi pučiamuoju priebalsiu: gesti „nykti ugniai, šviesai; blèsti“. Vienintelè šio veiksmažodžio esamojo laiko forma - sta kamieno - užfiksuota „Purpuroje“. Tokia morfologinė struktūra puikiai įformina savaiminị laipsniškai kintantị

2 Telšiškio autoriaus Mykolo Karpavičiaus „Kozoniuje“, kuris išleistas 30 metų vèliau nei „Ziwatas“, iš viso paliudytos trys na kamieno formos, plg. prażun MK1794 6 żun MK1794 6, żununti (musu żiamy) MK1794 19, greta kurių, beje, dar fiksuota ir gretutinè intarpinè lytis żuwuntius (mus) MK1794 17. 
veiksmą, nors senuosiuose XVI-XVII a. raštuose vis dar fiksuota senesnioji intarpinè forma (žr. Mikašauskienė 2019, 194). „Ziwate“ ir „Purpuroje“ paliudyta konstrukciškai ikoniška šio veiksmažodžio o kamieno būtojo laiko forma.

3 lentelè

\begin{tabular}{|l|l|l|l|}
\hline Veiksmažodis & „Ziwatas“ & „Purpura“ & Kiti autoriai \\
\hline gesti & - & gięst* Purp187v10 & \multirow{2}{*}{ - } \\
\cline { 2 - 4 } & użgiefa Zw33314 & ożgiesa Purp73r29 & \\
\hline
\end{tabular}

Apie šiaurès žemaičiu tarme rašytiems raštams būdingą priebalsių minkštumo žymèjimą žr. Girdenis 1997, 28; Subačius 1998, 56.

2. Ilgosios šaknies veiksmažodžiai

Analizuojamuose raštuose užfiksuoti 25 ilgosios šaknies veiksmažodžiai, 22 iš jų turi paliudytas esamojo ir / arba būtojo laiko formas.

2.1. Veiksmažodžiai su mišriuoju dvigarsiu šaknyje

12 sta kamieno veiksmažodžiu šaknyje turi mišrųij dvigarsịi: alkti „alkị kęsti, norèti valgyti“, alpti „netekti sąmonès, leipti“, gąsti „staigiai pabūgti, pabijoti“, girsti ,imti girdèti; gauti žinią, patirti“, grimzti „,skęsti, nerti, garmèti“, grižti „,eiti atgal“, ilsti „vargti, silpti, netekti kvapo“, kalsti „kaltam darytis, nusidèti“, skęsti „žūti vandenyje, prigerti; grimzti vandenyje“, tirpti „lydytis, leistis; leidžiantis nykti“, vargti „sunkiai, vargingai gyventi, skursti“, virsti „svirti, linkti į kurią nors pusę; darytis kokiam, tapti kuo“.

4 lentelè

\begin{tabular}{|l|l|l|l|}
\hline $\begin{array}{l}\text { Veiks- } \\
\text { mažo- } \\
\text { dis }\end{array}$ & „Ziwatas“ & "Pur pura“ & Kiti autoriai \\
\hline alpti & $\begin{array}{l}\text { alpfta Zw2918, } \\
\text { alpftates Zw16118 }\end{array}$ & alpstos Purp302v18 & - \\
\cline { 2 - 4 } & $\begin{array}{l}\text { alpa Zw16216 } \\
\text { apalpa Zw1785 }\end{array}$ & alpa Purp107r4 & - \\
\hline alkti & - & - & - \\
\cline { 2 - 4 } & $\begin{array}{l}\text { alkaw Zw31522, 3161 } \\
\text { alka Zw9214, 11620 }\end{array}$ & alka Purp180r25 & - \\
\hline
\end{tabular}




\begin{tabular}{|c|c|c|c|}
\hline $\begin{array}{l}\text { Veiks- } \\
\text { mažo- } \\
\text { dis }\end{array}$ & „Ziwatas“ & „Purpura“ & Kiti autoriai \\
\hline \multirow[t]{2}{*}{ gąsti } & - & - & - \\
\hline & $\begin{array}{l}\text { nufyganda } \mathrm{Zw} 4212-13 \\
\text { nufygąda } \mathrm{Zw} 24520 \\
\text { parfygada } \mathrm{Zw} 357\end{array}$ & $\begin{array}{l}\text { parsyganda Purp153v15 } \\
\text { parsygonda Purp113r16 }\end{array}$ & persigąnda VPJ1863 102 \\
\hline \multirow[t]{2}{*}{ girsti } & - & - & - \\
\hline & $\begin{array}{l}\text { yfzgyrdaw Zw1916-17 } \\
\text { yfzgyrda Zw88, 1414 }\end{array}$ & iszgiyrda Purp46r13 & iszgirdau VPJ1863 40 \\
\hline \multirow[t]{2}{*}{ grimzti } & - & - & - \\
\hline & grimzda Zw8320, 845 & pagrimzda Purp37r9 & - \\
\hline \multirow[t]{2}{*}{ grižžti } & $\begin{array}{l}\text { griżta Zw24523 } \\
\text { griszta Zw221 } \\
\text { fugrifzta } 3 Z w 2425\end{array}$ & - & $\begin{array}{l}\text { grisztąntius VVK1868 } 49 \\
\text { sugriźa VVK1868 } 9\end{array}$ \\
\hline & $\begin{array}{l}\text { pagriża Zw1209 } \\
\text { fugriźa Zw2819, } 7828 \\
\text { sugriza } Z w 513\end{array}$ & $\begin{array}{l}\text { griża Purp109v9 } \\
\text { pagriżau Purp118r20 } \\
\text { pagrizosi Purp209v20 }\end{array}$ & $\begin{array}{l}\text { sugriźaj VPJ1863 } 3 \\
\text { sugriźau VPJ18639 } \\
\text { sugriźom VPJ1863 } 30\end{array}$ \\
\hline \multirow[t]{2}{*}{ ilsti } & - & - & - \\
\hline & apylfa Zw2027 & - & - \\
\hline \multirow[t]{2}{*}{ kalsti } & & - & - \\
\hline & $\begin{array}{l}\text { nukalta Zw21661 } \\
\text { nukaltaw Zw3412 }\end{array}$ & - & - \\
\hline \multirow[t]{2}{*}{ tirpti } & - & tyrpst Purp134r26 & - \\
\hline & - & - & sutirpa VPJ1863 104 \\
\hline \multirow[t]{2}{*}{ vargti } & - & - & wargstu VVK1868 25 \\
\hline & nuwarga $\mathrm{Zw} 1165$ & $\begin{array}{l}\text { nuwarga Purp56r21 } \\
\text { nuwargosi Purp220v26 }\end{array}$ & - \\
\hline \multirow[t]{2}{*}{ virsti } & - & pawyrst Purp187v13 & - \\
\hline & pawyrta Zw14225 & - & $\begin{array}{l}\text { iszwirta VPJ1863 } 43 \\
\text { pawirta VPJ1863 } 28 \\
\text { pavirto S. Dauk. }\end{array}$ \\
\hline
\end{tabular}

2.1.1. Esamasis laikas. Analizuojamuose šaltiniuose dominuoja reguliarios mišrųii dvigarsį šaknyje turinčiu sta kamieno veiksmažodžių paradigmos, semantinis ir konstrukcinis tiriamųjų veiksmažodžių kodavimas yra optimalus - semantinès veiksmažodžiu charakteristikos (savaiminis / terminatyvinis veiksmas) $)^{3}$ įtvirtinamos morfologiniu žymikliu -sta. Daukanto ir Valančiaus

3 Daugiau apie intarpinių ir sta kamieno veiksmažodžių semantikos ypatybes žr.: Mikašauskienė 2018, 143-219; Arkadjevas 2008, 1-27; Pakalniškienė 1996a, 1996b, 2000 . 
darbuose taip pat dominuoja stabilios sta kamieno esamojo laiko formos, kurios paklūsta paradigmų struktūros sąlygoms, daugelis užfiksuotų sta kamieno veiksmažodžiu paliudyti ir „Kretingos tarmès žodyne“.

2.1.2. Būtasis laikas. Iš surinktų duomenų matyti, jog būtojo laiko formos analizuojamuose raštuose neįvairuoja, paliudytos tik o kamieno formos, atitinkančios sta kamieno veiksmažodžių paradigmų sąlygas. Formaliosios struktūros variacijų neaptikta nei Valančiaus ir Daukanto darbuose, nei „Kretingos tarmès žodyne“.

2.2 Veiksmažodžiai su ilguoju balsiu ir dvibalsiu šaknyje

Tirtuose šaltiniuose užfiksuoti du veiksmažodžiai, šaknyje turintys dvibalsį: bliesti „blykšti, balti“ ir gaišti „laiką veltui leisti, trukti; nykti, dingti, prapulti“. Sta kamieno veiksmažodžių, kurių šaknyje yra ilgasis balsis, aptikta devyni: klysti „klaidingai ką daryti, apsirikti; tolintis, skirtis“, nykti „mažèti, gaišti, baigti egzistuoti“, pykti ,jausti pyktį“, plyšti „rastis plyšiams, skylèms, skilti ị dalis, driksti, trūkti, sprogti“, plūsti ,gausiai, smarkiai tekèti, lietis, piltis“, mokti „mokytis“, trokšti „labai norèti gerti; labai norèti, geisti“, trūkti „stigti, stokoti reikiamo kiekio“, vysti „pamatyti“.

5 lentelè

\begin{tabular}{|c|c|c|c|}
\hline $\begin{array}{l}\text { Veiksma- } \\
\text { žodis }\end{array}$ & „Ziwatas“ & „Purpura“ & Kiti autoriai \\
\hline \multirow[t]{2}{*}{ aušti } & - & ausztąnt Purp80r24 & \begin{tabular}{|l} 
auszta VPJ1863 84 \\
iszauszt VVK1868 44
\end{tabular} \\
\hline & - & - & - \\
\hline \multirow[t]{2}{*}{ bliesti } & - & - & - \\
\hline & yfzblieda Zw201 ${ }_{15-16}$ & - & - \\
\hline \multirow[t]{2}{*}{ klysti } & - & $\begin{array}{l}\text { klistontej Purp30r11; } \\
\text { Purp135v23 }\end{array}$ & - \\
\hline & - & $\begin{array}{l}\text { klidau Purp11r17 } \\
\text { paktidau Purp182r14 }\end{array}$ & paklidau VPJ1863 61 \\
\hline \multirow[t]{2}{*}{ mokti } & - & - & - \\
\hline & yfzmoka $\mathrm{ZwV}_{5}$ & - & iszmoka VPJ1863 4 \\
\hline
\end{tabular}




\begin{tabular}{|c|c|c|c|}
\hline $\begin{array}{l}\text { Veiksma- } \\
\text { žodis }\end{array}$ & „Ziwatas“ & „Purpura“ & Kiti autoriai \\
\hline \multirow[t]{2}{*}{ nykti } & - & $\begin{array}{l}\text { nikst Purp187v12 } \\
\text { nikstonti Purp172r16 } \\
\text { nikstontys Purp155r11 }\end{array}$ & - \\
\hline & - & $\begin{array}{l}\text { isznika Purp8v13, } \\
\text { ysznika Purp34r8 } \\
\text { isz nika Purp36r20 }\end{array}$ & - \\
\hline \multirow[t]{2}{*}{ pykti } & - & - & - \\
\hline & fupika $\mathrm{ZwVII}_{23}, 200_{4}$ & - & $\begin{array}{l}\text { nepikau VPJ1863 } 42 \\
\text { nesupikaj VPJ186391 }\end{array}$ \\
\hline \multirow[t]{2}{*}{ plyšti } & plifzta Zw128 24 & - & - \\
\hline & - & - & - \\
\hline \multirow[t]{2}{*}{ plūsti } & - & $\begin{array}{l}\text { plust Purp26r21 } \\
\text { plustos Purp85v3 } \\
\text { plustonty Purp6r18 }\end{array}$ & - \\
\hline & - & płuda Purp84r6 & - \\
\hline \multirow[t]{2}{*}{ trokšti } & $\begin{array}{l}\text { trokfztu } \mathrm{Zw} 11_{20}, \\
\text { trokfzti } \mathrm{Zw} 240_{22} \\
\text { trokfztate } \mathrm{Zw} 241_{4} \\
\text { trokfzta } \mathrm{Zw} 29_{22}, 63_{15}, 64_{5}\end{array}$ & $\begin{array}{l}\text { troksztu Purp19r14 } \\
\text { trokszt Purp198v25 } \\
\text { trokszti Purp26r17 } \\
\text { troksztantims } \\
\text { Purp26r19 } \\
\text { troksztąti Purp261r20 }\end{array}$ & - \\
\hline & 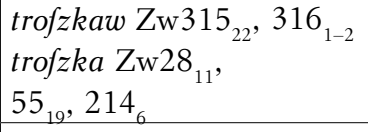 & troszka Purp21r19 & - \\
\hline \multirow[t]{2}{*}{ trūkti } & - & netrukst Purp249r19 & trukst VPJ186393 \\
\hline & truka Zw203 & patruka Purp154r14 & $\begin{array}{l}\text { nutruka VPJ1863 } 13 \\
\text { netruka VPJ1863 } 101 \\
\text { pritruko VPJ1863 } 6\end{array}$ \\
\hline \multirow[t]{2}{*}{ vysti } & - & - & - \\
\hline & $\begin{array}{l}\text { yfzwidaw } \mathrm{Zw} 38_{16}, 201_{24} \\
\text { yfzwiday } \mathrm{Zw} 271_{19} \\
\text { yfzwida } \mathrm{Zw} 19_{7}, 25_{19}\end{array}$ & - & $\begin{array}{l}\text { iszwidau VPJ1863 } 20 \\
\text { iszwida VVK1868 } 3\end{array}$ \\
\hline
\end{tabular}


Ilgạii balsị ir dvibalsị šaknyje turintys sta kamieno veiksmažodžiai neturi struktūrinių skirtumų, visuose tiriamuose šaltiniuose nuosekliai vartojamos sta kamieno esamojo laiko ir $o$ kamieno būtojo laiko formos. Užrašytų veiksmažodžių konstrukcinis kodavimas vienodas, optimalus, daugelis paliudytų veiksmažodžių yra morfosemantiškai skaidrūs, mat kategorinè semantika (mutatyvas, intranzityvas, dažnai rezultatyvas) reiškiama morfologiniu žymikliu - formantu sta.

\section{Išva dos}

1. „Ziwato“ ir šimtmečiu vèliau išleistos „Purpuros“ intarpiniai ir sta kamieno veiksmažodžiai sudaro itin stabilią sistemą, kurios ryškių skirtumų nepastebėta nei lyginant juos su Valančiaus ir Daukanto, nei su „Kretingos tarmès žodyno“ duomenimis. Morfologinè analizuojamų veiksmažodžiu struktūra kelių šimtų metų laikotarpiu kito labai nedaug, pastebėta tik intensyvesnè na kamieno ekspansija, būdinga tiems trumposios šaknies veiksmažodžiams, kurių šaknies finaleje yra sonantai $v$ ir $j$. Kretingiškių tarmèje na kamieno ekspansijos užuomazgas iliustruoja „Ziwate“ (1759) užfiksuoti duomenys (užrašyta vienintelè na kamieno forma), šio kamieno formų skaičius tolydžio augo „Purpuroje“ (užfiksuotos trys veiksmažodžių na kamieno formos) bei Valančiaus ir Daukanto raštuose, o jo plitimo kulminacija atsispindi XX a. antrojoje pusėje surinktame „Kretingos tarmés žodyne“.

2. Tirtuose raštuose užfiksuoti 28 trumposios šaknies intarpiniai ir sta kamieno veiksmažodžiai: 14 iš jų šaknis baigiasi sprogstamuoju priebalsiu (CVT tipas), 13 veiksmažodžiu su sonantine šaknies finale (CVR tipas), vieno veiksmažodžio finaleje yra pučiamasis priebalsis ( $C V S$ tipas). Analizuoti trumposios šaknies veiksmažodžiai sudaro konkrečius struktūrinius modelius priklausomai nuo šaknies struktūros: esamojo laiko atžvilgiu trumposios šaknies $C V T$ tipo veiksmažodžiai tirtuose raštuose intarpiniai, $C V R$ tipo veiksmažodžių struktūra koreliuoja su šaknies finalès sonanto tipu: sonantais $m, n, l$ ir $r$ besibaigiantys veiksmažodžiai turi sta kamieno, o $v$ ir $j-n a$ kamieno formas. CVS tipui priskirtinas vienas „Purpuroje“ paliudytas veiksmažodis, kurio esamojo laiko forma jau perejusi į sta kamieną. Dominuoja o kamieno būtojo laiko formos.

3. Ilgosios šaknies veiksmažodžių (jų užrašyta 25) sistema itin stabili ir vienoda visuose tirtuose šaltiniuose - paliudytos tik konstrukciškai ikoniškos esamojo laiko sta kamieno ir būtojo laiko o kamieno formos. 


\section{Literatūra ir šaltiniai}

Aleksandravičius, Palionis 1998 - Juozas Aleksandravičius, Jonas Palionis [Rec.:] „Aleksas Girdenis, Danutė Girdenienè, 1759 metu „Ziwato“ indeksas. Vilnius: Mokslo ir enciklopediju leidybos institutas, 1997, 462 p.“. Baltistica 33 (1), 126-130.

Arkadjevas 2008 - Piotras Arkadjevas. Lietuvių kalbos pirminiu veiksmažodžiu klasių semantika tipologinių duomenų kontekste. Acta Linguistica Lithuanica LIX, 1-27.

Girdenis 1997 - Aleksas Girdenis, Danute Girdenienè. 1759 metu „Ziwato“ indeksas. Vilnius: Mokslo ir enciklopedijų leidybos institutas.

Girdenis 2005 - Aleksas Girdenis. Rankraštinès Purpuros chronologiniai santykiai su 1759 metu Žyvatu. Acta Linguistica Lithuanica 7, 17-44.

Kazlauskas 2000 - Jonas Kazlauskas. Rinktiniai raštai I: Lietuvių kalbos istorine gramatika. Vilnius: Mintis.

Kiseliūnaitè 1991 - Dalia Kiseliūnaitè. Šakninių veiksmažodžių struktūros įvairavimas baltų kalbose. Vilnius: Humanitarinių mokslų daktaro disertacija. Rankraštis.

KretŽ - J. Aleksandravičius. Kretingos tarmès žodynas. Vilnius: Lietuvių kalbos instituto leidykla, 2011.

Mikašauskienė 2018 - Raimonda Mikašauskienè. Intarpiniai ir sta kamieno veiksmažodžiai senojoje lietuvių raštijoje. Humanitarinių mokslų daktaro disertacija. Klaipèdos universitetas.

Mikašauskienè 2019 - Raimonda Mikašauskienè. Trumposios šaknies intarpinių ir sta kamieno veiksmažodžių morfologinè struktūra senuosiuose žemaičių raštuose. Res Humanitariae, 25, 184-199.

MK1794 - Mykolas Karpavičius. Kozonius. Vilnius, 1794. Prieiga internetu: http://www.atmintis. mb.vu.lt/kolekcijos/VUB01_000394043

Pakalniškienè 1996b - Dalia Pakalniškienè. Naujausias intarpinių ir sta-kamienių veiksmažodžių sluoksnis: imitatyvai. Baltistica 31 (1), 49-52.

Pakalniškienė 1997 - Dalia Pakalniškienè. Senosios balsių kaitos atspindžiai intarpinių veiksmažodžių šaknyse. Vilnius: VIII tarptautinio baltistų kongreso „Baltų kalbos XVI ir XVII amžiuje“ pranešimų tezès, p. 108-109.

Pakalniškienè 2000 - Dalia Pakalniškienè. Lietuvių kalbos intarpiniai ir sta-kamieniai denominatyvai. Veiksmažodžio raidos klausimai. „Tiltai““, 1 priedas, 71-89.

Purpura 2009 - Purpura iszganima mukos Iezusa. Pagal rankrašti parengè ir teksto mokslini tyrimą parašè Aleksas Girdenis. Vilnius: Vilniaus universiteto leidykla.

Rosinas 1995 - Albertas Rosinas. Baltų kalbu įvardžiai: morfologijos raida. Vilnius: Vilniaus universitetas.

Subačius 1998 - Giedrius Subačius. Žemaičiu bendrinès kalbos idëjos. XIX a. pradžia. Vilnius: Mokslo ir enciklopedijų leidybos institutas.

Svensson 2005 - Miguel Villanueva Svensson. The Baltic $\bar{e}$-preterit revisited. Baltistika, 6 priedas, $239-252$.

VPJ1863 - Motiejus Valančius. Pałąngos Juze. Vilnius, 1863. Prieiga internetu: https://www.epaveldas.lt/object/recordDescription/LNB/C1B0002993455

VVK1868 - Motiejus Valančius. Wajku kningiele. 1868. Prieiga internetu: https://www.epaveldas. 1t/object/recordDescription/LNB/C1B0002982829

Ziwatas 1998 - 1759 metu „Ziwatas“. Parengè Aleksas Girdenis ir Petras Skirmantas. Vilnius: Mokslo ir enciklopedijų leidybos institutas.

Vaičiakauskytė 2002 - Sonata Vaičiakauskytè. 1759 metu „Ziwato“ vardažodžio linksniavimo sistema. Daktaro disertacija. Vilniaus pedagoginis universitetas.

Venckutè, Subačius 1999 - Regina Venckutė, Giedrius Subačius [Rec.:] „Aleksas Girdenis, Danutė Girdenienè, 1759 metu „Ziwato“ indeksas, 1997; 1759 metu „Ziwatas“, faksimilinis leidimas, parengė Aleksas Girdenis, Petras Skirmantas“, 1998. Acta Linguistica Lithuanica 1, 192-198. 


\section{Raimonda Mikašauskienè}

\section{THE MORPHOLOGICAL STRUCTURE OF INFIXED AND $S T A-S T E M$ VERBS SHOWN IN 'ZIWATAS' AND 'PUR PURA'}

Summary

The article focuses on the morphological structure of infixed and sta-stem verbs in two written sources in the north Samogitian dialect of Kretinga, Ziwatas and Purpura in particular. Purpura is aproximately a hundred years older than Ziwatas (1759), so it could be stated that both written sources reflect different developmental stages of the same Kretinga dialect. The aim of the article is to compare the morphological structure of infixed and sta-stem verbs in these sources, and to further compare them to data extracted from the dictionary of the Kretinga dialect, by highlighting the changes and innovations that took place in the verbal system. The data gathered is further compared to linguistic facts regarding two authors using the same Kretinga dialect, Motiejus Valančius and Simonas Daukantas, and also to data provided by the Dictionary of the Lithuanian Language.

The verbs are classified into two major groups of short-root and long-root verbs. The analysis shows that the morphological structure of short-root verbs in Samogitian writings displays a clear correlation with the consonantal structure of the root of the verb: as for the present tense, the short-root verbs belonging to the $C V T$ type in the sources analysed are infixed; the structure of $C V R$ verbs correlates with a specific type of the sonant; those verbs ending in $m, n, l$ and $n$ have sta-stem forms attested, while those ending in $v$ and $j$ belong to na stem. There is only one verb ascribed to the CVS type, the present tense form of which is that of $s t a$-stem. In the majority of cases, $o$-stem past tense forms preside.

As for the long-root verbs, in the works of the authors mentioned, only stable sta-stem structures complying with the paradigm structure requirements prevail; thus, the majority correspond to forms used in the contemporary Samogitian dialect. Semantic and constructional coding in the majority of attested verbs is optimal: the semantic characteristics of the verbs in question (namely, spontaneous, reflexive, intransitive and frequently resultative action) are reinforced by the morphological marker sta.

It can be stated that the morphological structure of the verbs analysed over a period of a hundred years changed only very slightly; only a more intensive expansion of the na-stem took place among the short-root verbs ending in the consonants $v$ and $j$. The collected empirical data reveals that the earliest form 
(the only one!) belonging to the na-stem was in Ziwatas, dating back to the end of the 18th century. Later Samogitian writings exhibit a subsequent rise in the use of na-stem forms, which reached a peak in the second half of the 20th century, as the data from the dictionary of the Kretinga dialect shows. 